\title{
Ground temperature measurement for mitigation of landslides: a case study in Japan and its application to Bhutan
}

\author{
${ }^{*}$ Tadashi Yasuda ${ }^{1}$, Atsuo Takeuchi ${ }^{2}$ and Tek Nath Kararia ${ }^{3}$ \\ ${ }^{1}$ JICA Bhutan Office, Thimphu, Bhutan \\ ${ }^{2}$ Natural Groundwater Research Institute, Japan \\ ${ }^{3}$ Thimphu City Corporation, Thimphu, Bhutan \\ (*Email: yassann.25.1@gmail.com)
}

\begin{abstract}
The rainwater penetrating the soil and reaching the zone of weakness develops lifting force, which leads overlying soil mass to slide. Hence, it is important to identify where groundwater exists or flows in the soil, as it indicates where to place countermeasure works. The ground temperature measurement is suitable for assessing groundwater condition, and is easily performed with simple instrument and tool. The result of analysing temperature distribution at the surveying site can provide information on groundwater flowing area. In this paper, we introduce the theory and practice of the ground temperature measurement first, then present a case study of successful landslide survey and mitigation work in Japan, and recommend to apply the similar initiative to the potential landslide area in Bhutan.
\end{abstract}

Keywords: landslide, rainfall, groundwater temperature, countermeasure, mitigation.

Paper Received: 17 May 2015

Paper Accepted: 16 January 2016

\section{INTRODUCTION}

Generally, landslide occurs after heavy rainfall. When the rain falls, part of it penetrates the soil, where it flows as groundwater, which develops lifting force that leads overlying soil mass to slide. Thus, it is important to identify where groundwater exists and/or flows in the soil, since it indicates where to prepare countermeasure works such as drilling wells for extracting groundwater to make the zone more stable.

This paper introduces the theory and practice of the ground temperature measurement first, then describes a case study of successful landslide survey and mitigation work in Japan, and finally discuss how to apply the initiative to possible landslide area in Bhutan.

\section{LANDSLIDE AND GROUNDWATER}

The landslide is generally classified into a number of categories by type of movement and material involved (Varnes 1978). The movement contains 6 types which are falls, topple, slides, lateral spreads, flows and complex, while the materials are classified into bedrock and engineering soil. The slide is divided into rotational and translational, and the engineering soil is divided into debris (coarse material) and earth (fine material). In this paper, landslide is defined as mass movement on slope, where in depth, a distinct zone of weakness exists that separates the overlying soil mass from stable underlying soil or rock.
Fig. 1 shows the schematic model of groundwater flow in the soil mass of landslide (Yasuda and Takeuchi 2012). Groundwater flows in a distinct weak zone to develop lifting force to overlain soil mass and make it slide.

This situation is explained by limit equilibrium slope stability equation as follows:

Fs (Factor of Safety) $=\mathrm{R}$ (Resistance force)/ D (Driving force)

$\mathrm{R}$ is proportional to - $\mathrm{u}$ (Lifting force at the bottom of overlain soil mass $=$ Groundwater level)

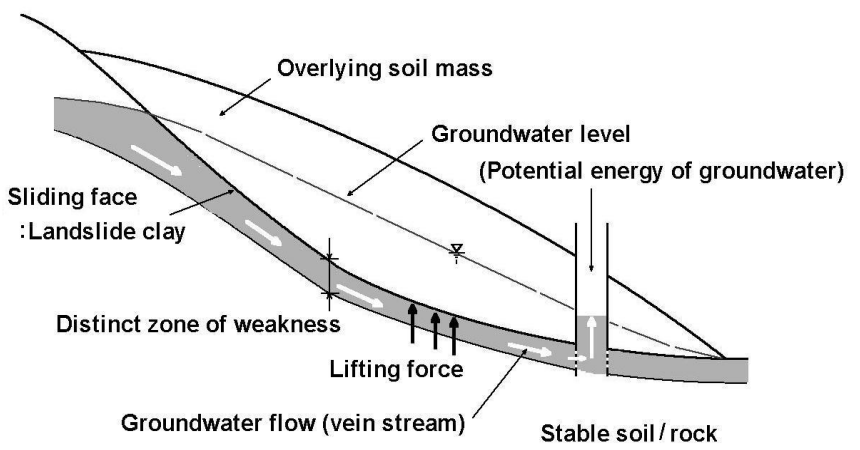

Fig. 1: Model of groundwater flow in the soil mass of landslide. 
If Factor of Safety (Fs) is more than 1.0, the slope is safe, but if it is less than 1.0, the slope is unstable and may slide. In case of $\mathrm{Fs}=1.0$, it is critical state of equilibrium. When water pressure at the bottom of overlain soil mass (u) increases, it means equivalent to groundwater level rising, and Factor of Safety, as well as Resistance force, become less and the slope will be unstable. So, it is effective to make groundwater level lower, as a result, the landslide movement will be stopping or keeping stable slope.

Fig. 2 shows a cut slope face of massive weathered mudstone in Japan (Yasuda and Takeuchi 2009). Groundwater seeping points distributed on the slope surfaces are believed to be groundwater flows as vein stream. This means that the seepage points have relatively higher permeability and consequently, groundwater flows selectively as stream veins in the ground behind slope.

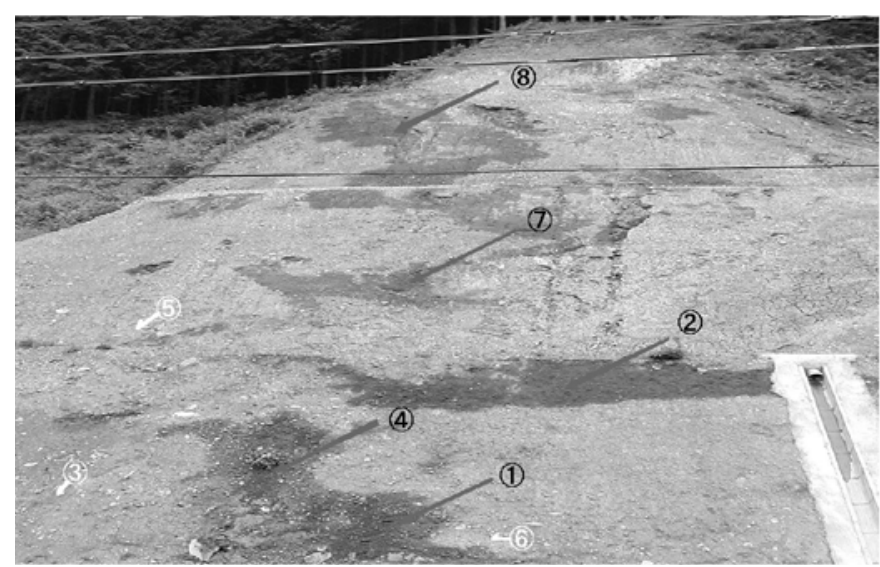

Fig. 2: Seepage of groundwater vein stream on a cut slope in Japan (1): seepage points).

Fig. 3 shows an example of making landslide more stable by withdrawing groundwater from the stream veins where groundwater flows (Yasuda and Takeuchi 2012). It makes groundwater level lower and increase Factor of Safety.

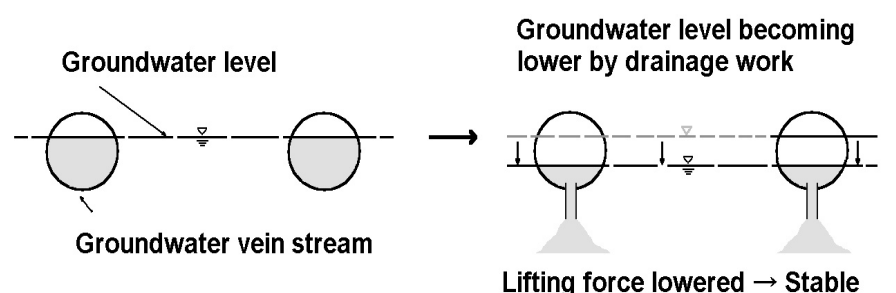

Fig. 3: Model of making landslide stable by extracting groundwater.

\section{GROUND TEMPERATURE MEASUREMENT AND GROUNDWATER VEIN STREAM}

As earlier mentioned, it is effective to make groundwater level lower by removing groundwater for stabilising landslide. If groundwater temperature is different from ground temperature, it can be detected where groundwater vein stream is. To know distribution of groundwater vein stream planar, it is effective to measure distribution of ground temperature.

In case of implementing the measurement, it is important to avoid negative effect during measuring such as temperature varying within a day at the site, which is obstacle against gathering correct data. Temperature can be considered constant within a day if the depth of measurement is $1 \mathrm{~m}$. This is the reason why $1 \mathrm{~m}$ depth ground temperature measurement is general way of ground temperature measurement.

Fig. 4 shows scheme of $1 \mathrm{~m}$ depth ground temperature measurement (Takeuchi 2013). In principle, ground temperature is higher or lower than groundwater temperature in summer or winter respectively. Groundwater vein stream is detected by the difference between the ground temperature and groundwater temperature. For implementation of $1 \mathrm{~m}$ depth ground temperature measurement, it is advised to arrange measuring points in regular pattern. Generally, the interval of each point is $5 \mathrm{~m}$ in vertical section, and 5 to $10 \mathrm{~m}$ in longitudinal section. If groundwater vein stream is smaller than the interval, it should be shortened for effective measurement.

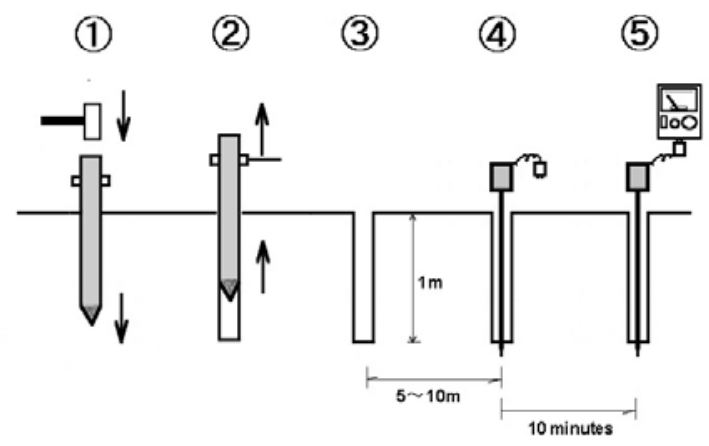

Fig. 4: Schematic view of $1 \mathrm{~m}$ depth temperature measurement.

Fig. 5 shows process and equipment of $1 \mathrm{~m}$ depth ground temperature measurement. The equipment consists of simple instruments such as temperature sensor, thermometer, steel cone bar for making holes, and hammer. The process is as following;

(1) Hammer steel cone bar into ground to make a hole of 1 $\mathrm{m}$ depth.

(2) Withdraw the bar.

(3) $1 \mathrm{~m}$ depth hole prepared.

(4) Set temperature sensor and leave for 10 minutes.

(5) Measure the temperature by the instrument.

After finishing the measurement, the analysis of the result should be performed by the process as follows:

(1) Correct error of Sensor, and setting of land condition and daily change in the temperature.

(2) Estimate normal $1 \mathrm{~m}$ depth ground temperature: Often using average of the temperature. 
As the process mentioned above is successfully done, distribution of groundwater vein stream on a map and cross sections can be expressed.

\section{A CASE STUDY IN JAPAN}

In Japan, there are many cases of ground temperature measurement in landslide investigation. We introduce a case study of the survey in northern Japan and its mitigation work using the result of the measurement (Yasuda et al. 2009). The landslide is situated deep in the mountain, at an altitude from $300 \mathrm{~m}$ to $400 \mathrm{~m}, 42^{\circ} 30^{\prime}$ ' north latitude and $140^{\circ} 40^{\prime}$ east longitude, Hidaka district, Hokkaido, Japan. The atmospheric temperature is $6.8^{\circ} \mathrm{C}$, the precipitation is $1,294 \mathrm{~mm}$, the snow depth is $182 \mathrm{~cm}$, which are annual averages from 1990 to 2014, respectively (Japan Meteorological Agency 2015).

The landslide became active in the summer of 2003 after heavy rainfall $(215 \mathrm{~mm})$ for 3 days until the rain stopped. Cracks were produced at the top and middle of the sliding soil mass and there maximum opening was around $20 \mathrm{~cm}$ per month from $18^{\text {th }}$ September. Geology of base rock is Kamuikotan metamorphic rocks group such as amphibolite and meta-sedimentary rocks with distinct cleavage (Yasuda et al. 2009).

The exploration map and the landslide profile are as shown in Fig. 7 and 8, respectively. They are based on the results of core boring and geophysical exploration. The whole landslide consists of small blocks. As the sliding face corresponding to the distinct zone of weakness of landslide was assumed to be too deep to detect groundwater vein stream in the upper area of the landslide, the ground temperature measurement was conducted within the lower right area. It was not done in thr lower left area where steep collapsed slope was distributed.

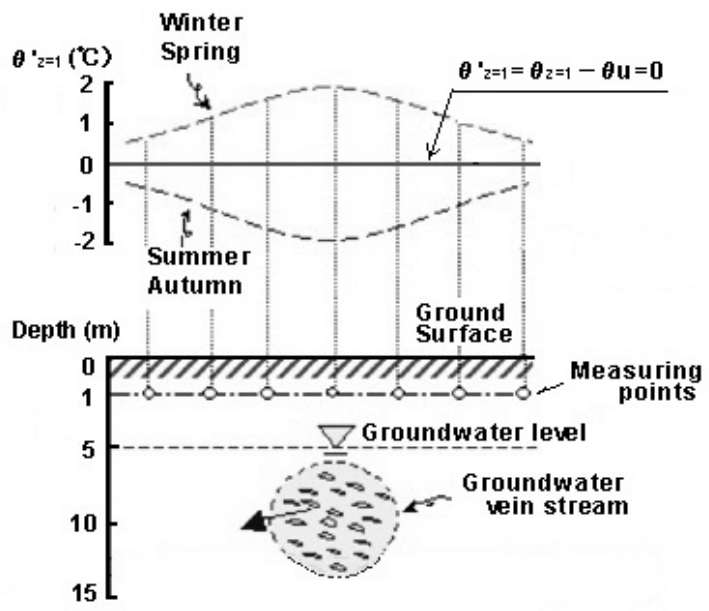

$$
\begin{aligned}
& \theta u \text { : Normal } 1 \mathrm{~m} \text { denth ground temperature } \\
& \theta_{z=1}: \text { Measured } 1 \mathrm{~m} \text { depth ground temperature } \\
& \theta_{z=1}^{\prime} \text { : Differential temperature between } \theta u \text { and } \theta_{z=1} \\
& \qquad \theta_{z=1}^{\prime}=\theta_{z=1}-\theta u
\end{aligned}
$$

Fig. 7: Exploration map of the landslide.

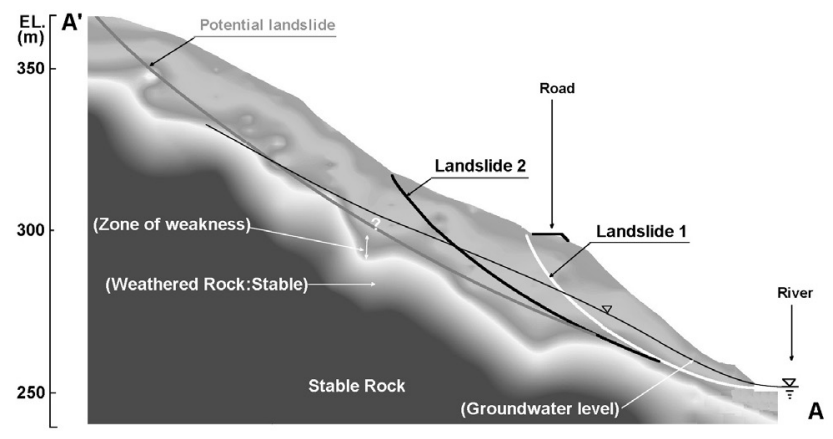

Fig. 8: Landslide profile (A-A' line in Fig. 7).

The result of the measurement is shown in Fig. 9. The normal $1 \mathrm{~m}$ depth temperature was $11.0{ }^{\circ} \mathrm{C}$ and groundwater temperature was 8.0. Fig. 9 shows the distribution of ground temperature on cross sections, by which we calculated the size and depth of the groundwater vein stream. In this case, by the solution obtained from calculation of the equation shown in Fig. 6 , the depth of epicenter of the groundwater vein stream circle was $7.0 \mathrm{~m}$, while size of the circle was $4.0 \mathrm{~m}$ in diameter by the calculation. The core boring and the groundwater logging called Multi temperature logging was also done to confirm this calculation at a point where groundwater vein stream exists, and the result of was proved to be appropriate in geological column in (Fig. 10). The groundwater vein stream existed in the distinct zone of weakness (that is sliding face) and loaded excessive pressure at the bottom of the overlying soil. So it was thought to be effective to withdraw the groundwater for landslide stabilisation.

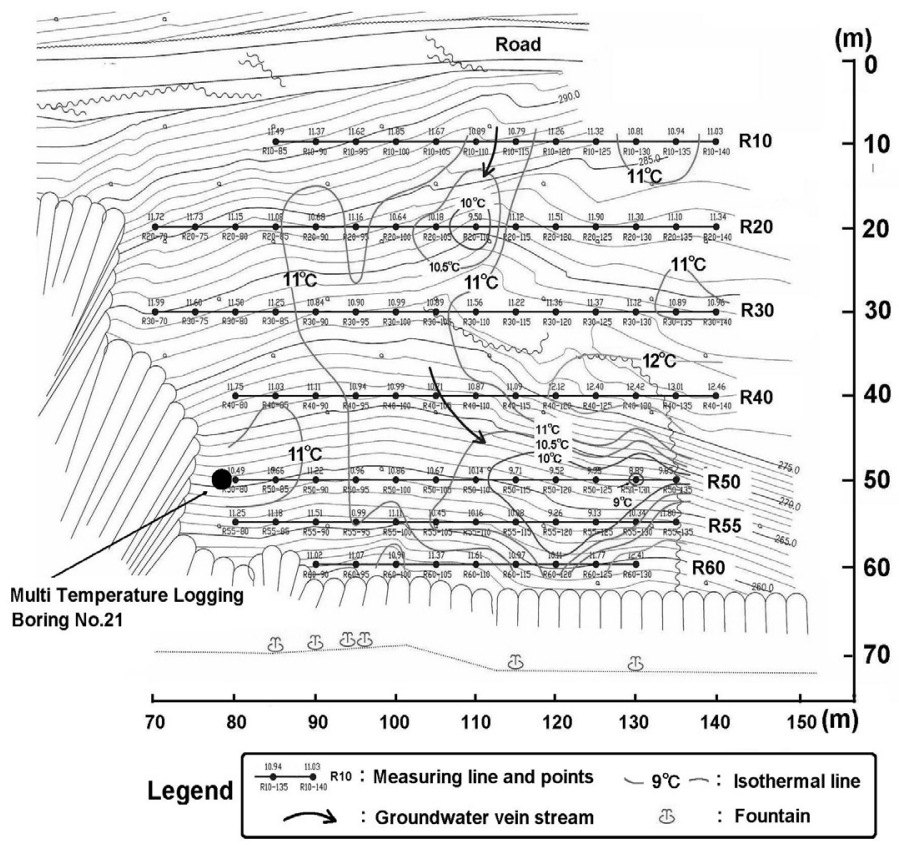

Fig. 9: Result of $1 \mathrm{~m}$ depth ground temperature measurement. 


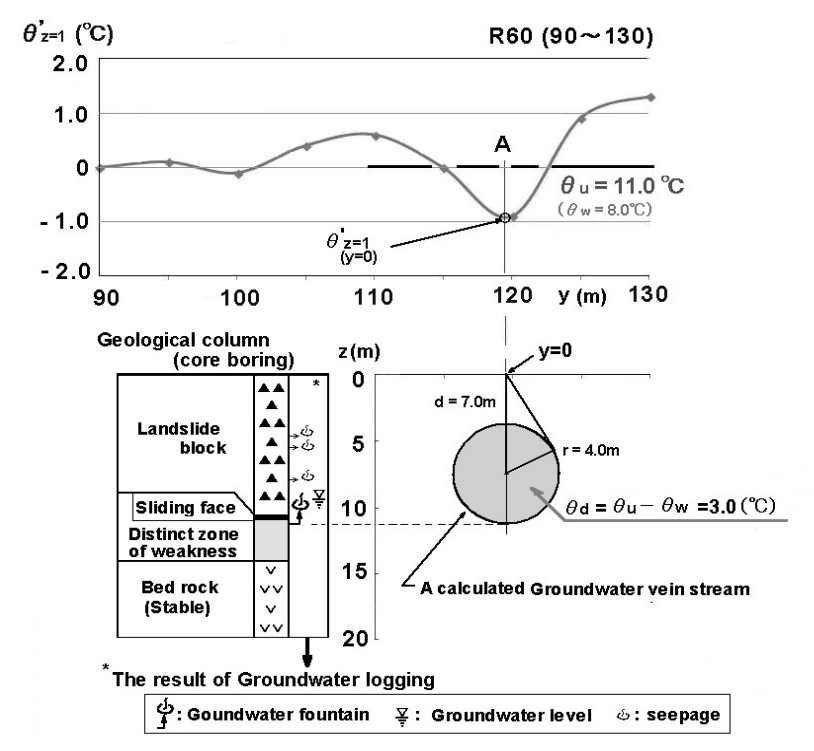

+ Legend of the each symbol is as the same as the one shown in Fig.5.

Fig. 10: The $1 \mathrm{~m}$ depth ground temperature on a cross section and groundwater vein stream calculated in theory.

Fig. 11 shows the mitigation work for making the landslide zone more stable. This was groundwater removal by drainage boring and well. The embankment work for increasing resistant force against landslide and concrete protection work against river erosion were also done. After these mitigation works, excessive groundwater drained, and consequently active landslide stopped and became stable. The landslide zone has been stable since the mitigation work completed more than ten years ago.

This example is successful case that landslide was made stabilised by ground temperature measurement and mitigation work was done according to the ground temperature.

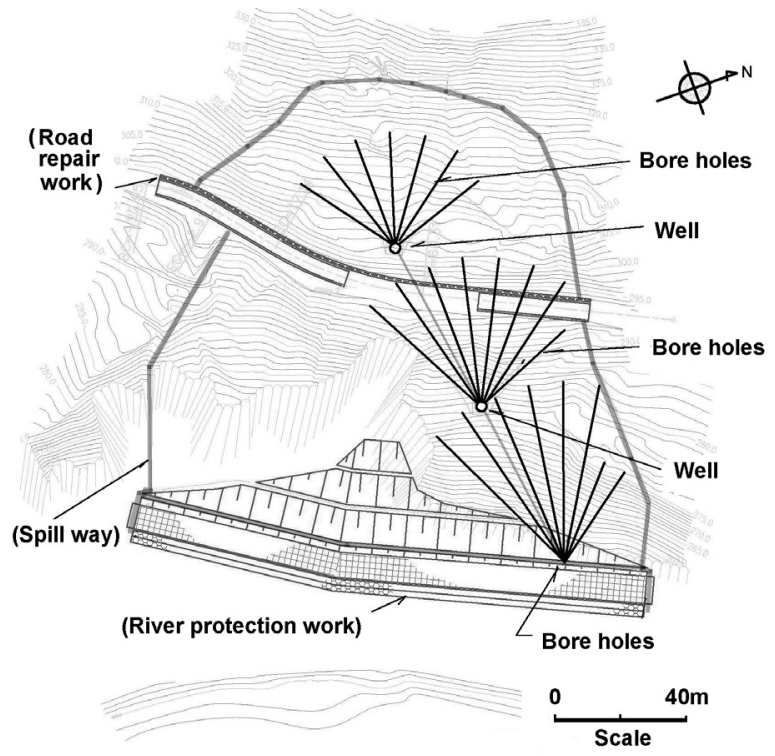

Fig. 11: Mitigation work consisting of wells and borings for groundwater drainage.
Ground temperature measurement for mitigation of landslides

\section{POTENTIAL LANDSLIDE IN BHUTAN}

Thimphu is the capital city of Bhutan, where the altitude varies from 2,300 $\mathrm{m}$ to $2,600 \mathrm{~m}$, and located around $27^{\circ} 30^{\prime}$ north latitude and $89^{\circ} 30^{\prime}$ east longitude. The topography of Thimphu and its suburb is valley in the mountain which consists of valley, terrace, fan and slopes. The bedrocks are divided into three groups: Tethys sedimentary rocks in the northern suburbs of Thimphu, gneiss of Higher Himalaya around the center of Thimphu, and meta-sedimentary rocks of Lesser Himalaya in southern suburbs. The average atmospheric temperature is $15^{\circ} \mathrm{C}$, which is almost as the same as Tokyo in Japan. Annual precipitation is about $600 \mathrm{~mm}$ that is half of that in Japan (RGB and JICA 2012). Most of precipitation concentrates in summer rainy season. The climate is dry and it is corresponding to the temperate climate.

In these three areas, the overlying soil mass is deposited soil or debris from slope behind or weathered rock on stable bed rock, and its bottom is formed the distinct zone of weakness and sliding face. So, the overlying soil mass develops landslide if it moves along the sliding face due to excessive pressure of groundwater in the distinct zone of weakness. Especially, the southern suburbs where Lesser Himalayan rocks are distributed, there are many potential landslides formed the soil mass mentioned above. The groundwater vein stream that exists and flows between base rock and overlying soil mass was found at the southern area.

Fig. 12 shows the geological map of Thimphu and its suburb (Yoshida 2012), where we are introducing five potential landslide areas and are considering the effectiveness of applying ground temperature measurement as geological survey for landslide. Details are shown in Table 1.
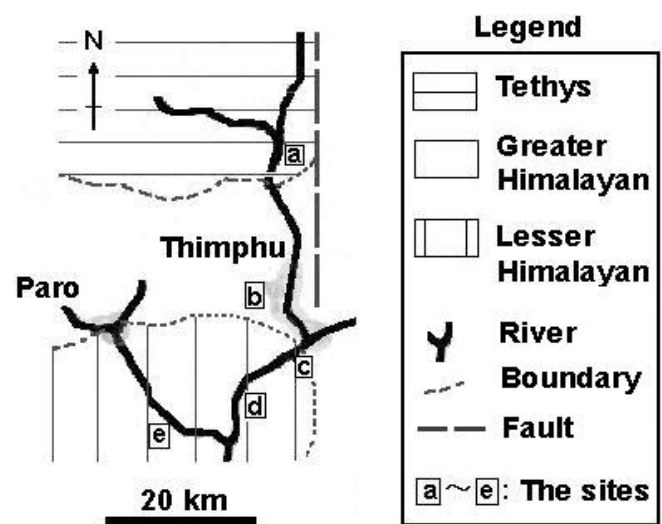

Fig. 12: Geological map of Thimphu and its suburb (modified after Yoshida 2012).

Table 1 shows that some explored potential landslides contain groundwater vein stream and the cause of sliding movement may be due to groundwater. They might be effective to mitigate movement of landslide by extracting groundwater and, consequently, recommended to conduct the ground temperature measurement in order to know from where to withdraw groundwater. 
Table 1: Feature of the potential landslides explored in Thimphu.

\begin{tabular}{|c|c|c|c|c|c|c|}
\hline No & Location & $\begin{array}{c}\text { Geology of } \\
\text { bed rock }\end{array}$ & $\begin{array}{c}\text { Size } \\
\left(\mathrm{km}^{2}\right)\end{array}$ & $\begin{array}{c}\text { Type } \\
\text { (slide) }\end{array}$ & Feature and Activities & $\begin{array}{c}\text { Groundwater } \\
\text { (Advisability*) }\end{array}$ \\
\hline $\mathrm{a}$ & $\begin{array}{l}\text { North } \\
\text { Thimphu }\end{array}$ & $\begin{array}{l}\text { Tethys } \\
\text { Sedimentary } \\
\text { Rocks } \\
\text { (Layered) }\end{array}$ & $0.2+$ & $\begin{array}{l}\text { Rotational- } \\
\text { debris }\end{array}$ & $\begin{array}{l}\text { - Roots bent } \\
\text {-Irregular shaped slope and } \\
\text { scarp }\end{array}$ & $\begin{array}{l}\text { A little } \\
\text { ( Good) }\end{array}$ \\
\hline $\mathrm{b}$ & $\begin{array}{l}\text { Central } \\
\text { Thimphu }\end{array}$ & $\begin{array}{l}\text { Higher Himalayan } \\
\text { Gneiss } \\
\text { (Plated) }\end{array}$ & $0.1 ?$ & $\begin{array}{l}\text { Translational } \\
\text { - rock }\end{array}$ & $\begin{array}{l}\text {-A little sliding as sheets } \\
\text { along opened foliations } \\
\text { (discontinuities). } \\
\text { - The size being unclear }\end{array}$ & $\begin{array}{l}\text { Assumed little } \\
\text { (Could be } \\
\text { good) }\end{array}$ \\
\hline $\mathrm{c}$ & $\begin{array}{l}\text { South } \\
\text { Thimphu }\end{array}$ & $\begin{array}{l}\text { Lesser Himalayan } \\
\text { Meta-Sed. Rocks } \\
\text { (Unknown) } \\
\text { Partially Higher } \\
\text { Himalayan? }\end{array}$ & $1.0+$ & $\begin{array}{l}\text { Rotational- } \\
\text { debris }\end{array}$ & $\begin{array}{l}\text {-Irregular shaped slope } \\
\text {-Distinct typical scarp } \\
\text {-Slope failures in the area } \\
\text {-Water flowing in the area }\end{array}$ & $\begin{array}{l}\text { Plenty } \\
\text { (Good) }\end{array}$ \\
\hline d & $\begin{array}{l}\text { South } \\
\text { Thimphu }\end{array}$ & $\begin{array}{l}\text { Lesser Himalayan } \\
\text { Meta-Sed. Rocks } \\
\text { (Thick soil } \\
\text { covered) }\end{array}$ & $1.0+$ & $\begin{array}{l}\text { Rotational- } \\
\text { earth(soil) }\end{array}$ & $\begin{array}{l}\text {-Small collapse at the face of } \\
\text { road cutting of gentle slope }\end{array}$ & $\begin{array}{l}\text { Existing } \\
\text { (Rather Good) }\end{array}$ \\
\hline e & $\begin{array}{l}\text { South } \\
\text { Thimphu } \\
\text { (Paro) }\end{array}$ & $\begin{array}{l}\text { Lesser Himalayan } \\
\text { Meta-Sed. Rocks } \\
\text { (Layered) }\end{array}$ & $0.2+$ & $\begin{array}{l}\text { Rotational- } \\
\text { debris } \\
\text { /earth(soil) }\end{array}$ & $\begin{array}{l}\text {-Small collapse at the face of } \\
\text { road cutting of valley deposit } \\
\text {-Fountain of groundwater } \\
\text { always flowing between } \\
\text { overlying soil and stable rock }\end{array}$ & $\begin{array}{l}\text { Plenty } \\
\text { (Good) }\end{array}$ \\
\hline
\end{tabular}

*Advisability means whether 'The ground temperature measurement' is recommended or not.

The potential landslide "No. a" formed by debris of Tethys sedimentary rocks is shown in Fig. 13 and 14. There is a scarp that indicates the overlying soil sliding. The bent roots are often found in the area, which seem to be evidence of sliding movement. And we recognised small water flow on surface. This potential landslide might move a little and be unstable because of groundwater.

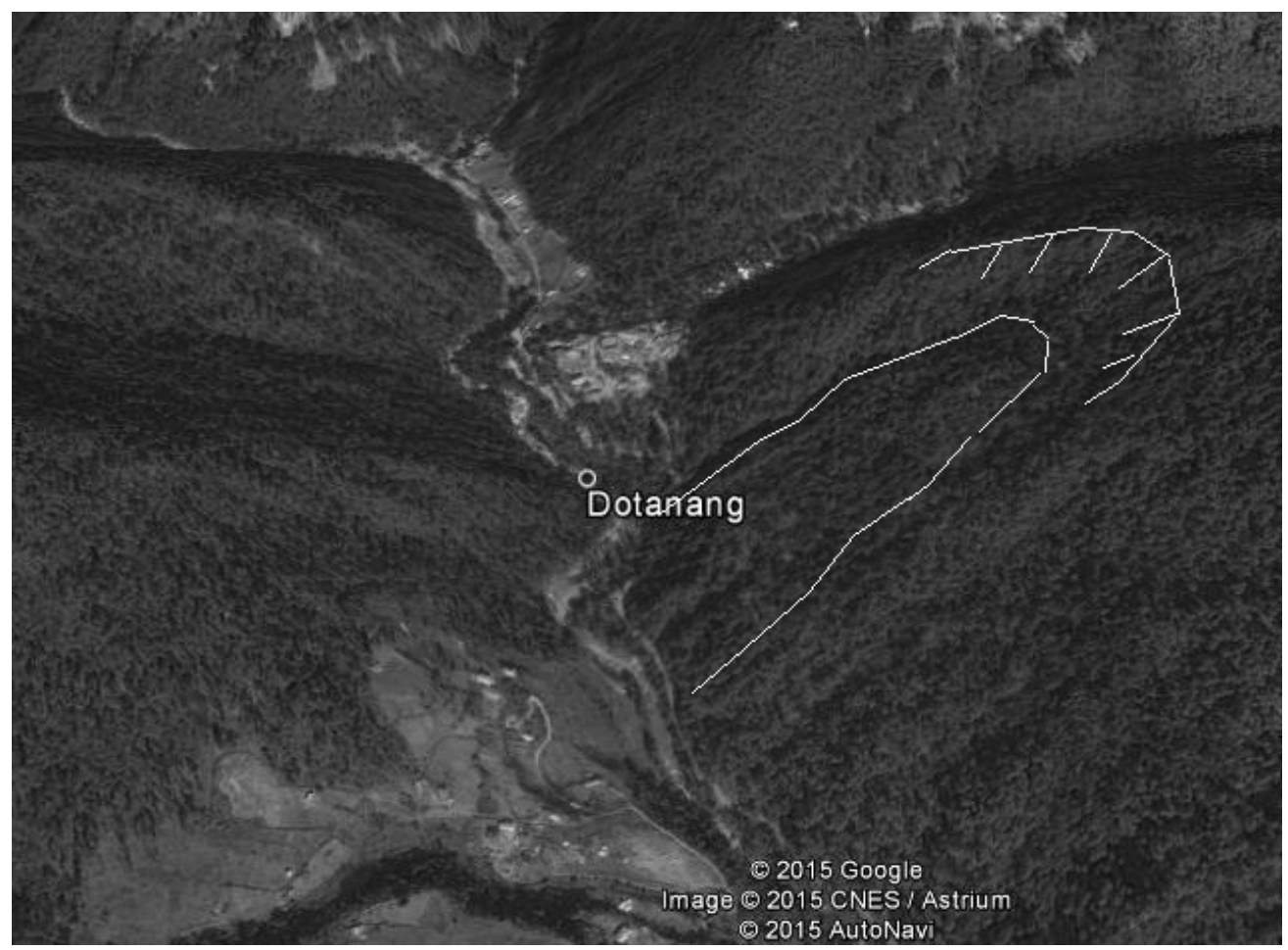

Fig. 13: Bird view of potential landslide 'No. a' (depicted from Google Earth). 


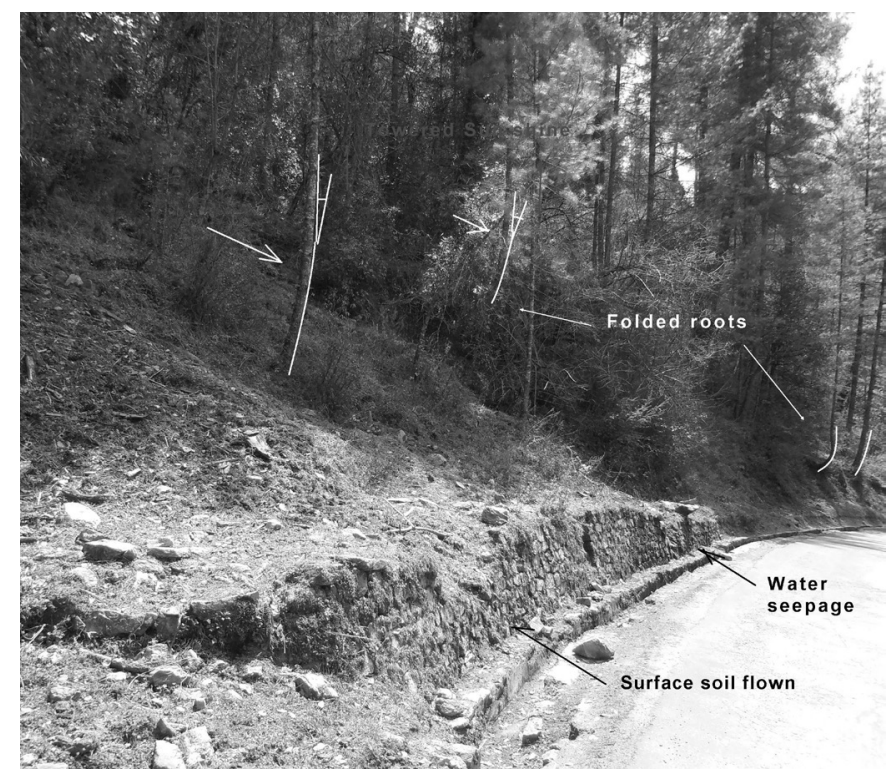

Fig. 14: Phenomenon of landslide in 'No. a' (roots bent, water seepage, surface soil flown).

The potential landslide "No. c" is big and is situated in the meta-sedimentary rocks of Lesser Himalayan group. It has typical shape of the rotational slide and there are many houes in this area as shown in Fig. 15. In the area there is small slope failure and water flow as shown in Fig. 16. The inhabitants told that no movement has been recognised for a long time. This potential landslide is presumed not to be unstable now, but the one of the cause of movement could be groundwater. The ground temperature measurement may be effective, but the thickness of the landslide seems to be much, so it is important to consider where this measurement can be effective. Measuring not in the whole area but the end of the landslide or the top of the one is recommended.

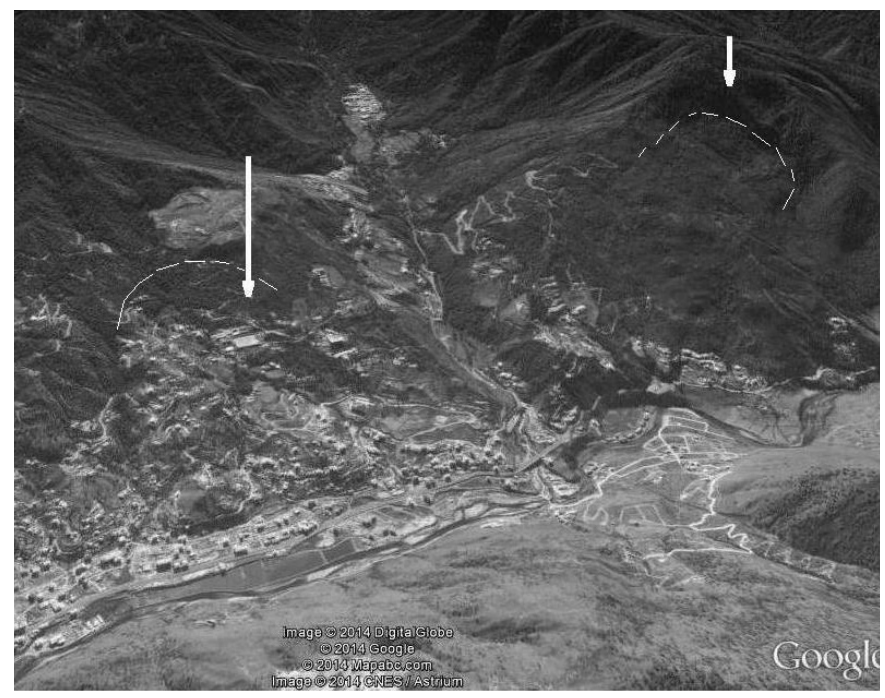

Fig. 15: Bird view of the potential landslide 'No. c' (cited from Google Earth).

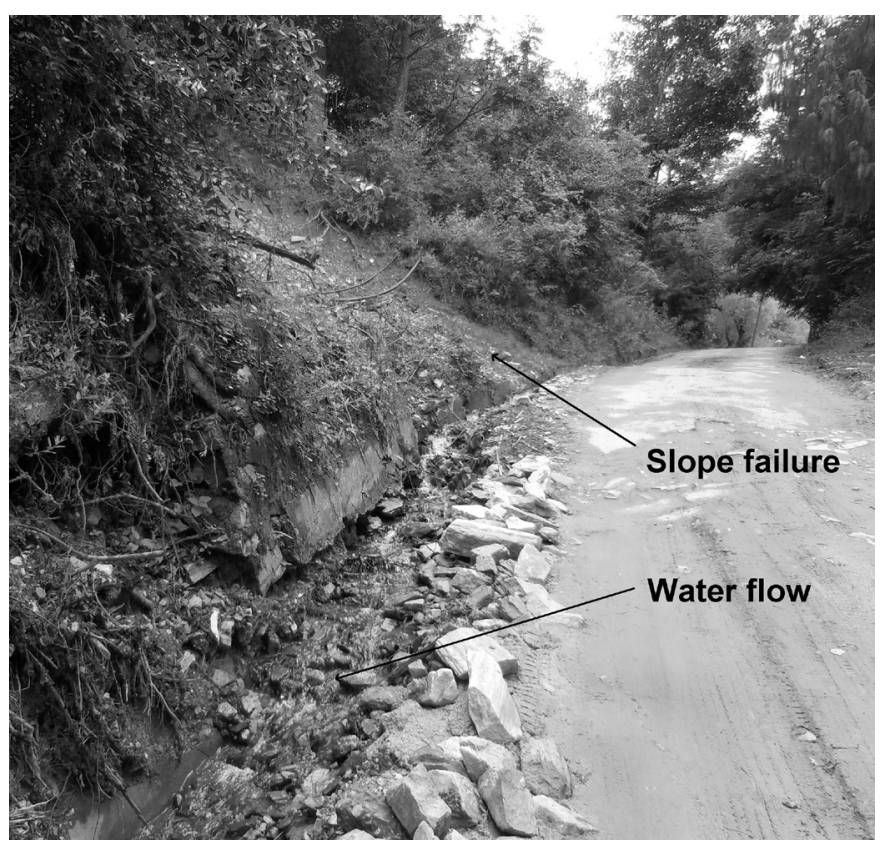

Fig. 16: Phenomenon of landslide in 'No. c' (small slope failure, water flow).

The potential landslide "No. e" formed by soil in the valley of meta-sedimentary rocks of Lesser Himalaya. Its distinct boundary between bedrock and overlying soil, and fountain is shown in Figs. 17 and 18. The fountain is from groundwater vein stream flowing through the zone of weakness with sliding face. There is small slump in the soil at the road cutting slope, and it might be evidence of moving very little. This potential landslide could be unstable if the groundwater increases.

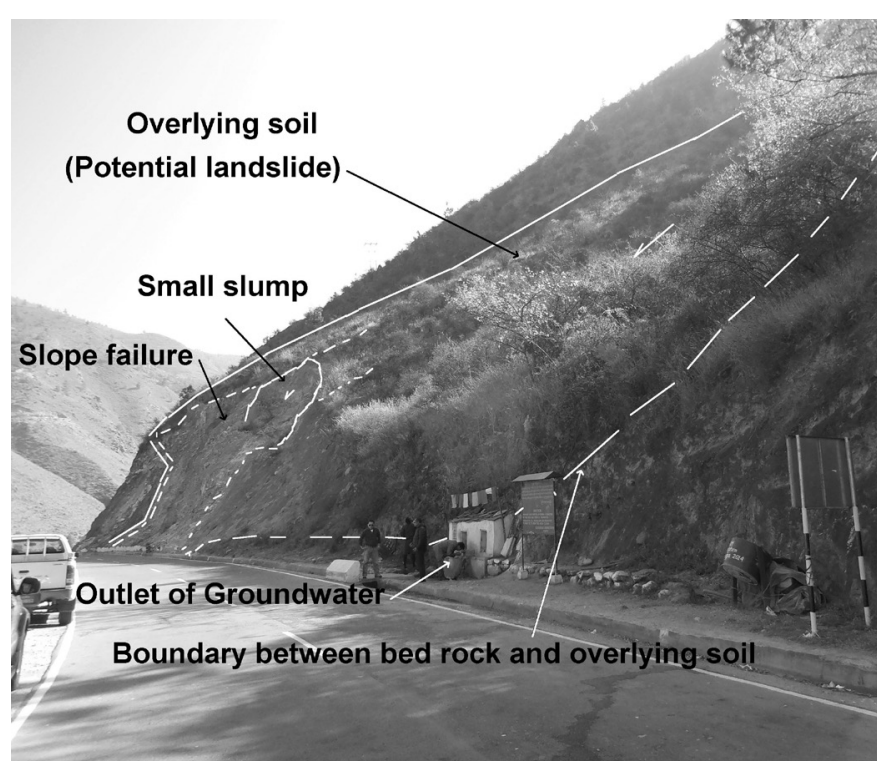

Fig. 17: Side view of the potential landslide 'No. e' (shape of overlying debris, distinct boundary between overlying soil and bed rock, small failure, fountain). 


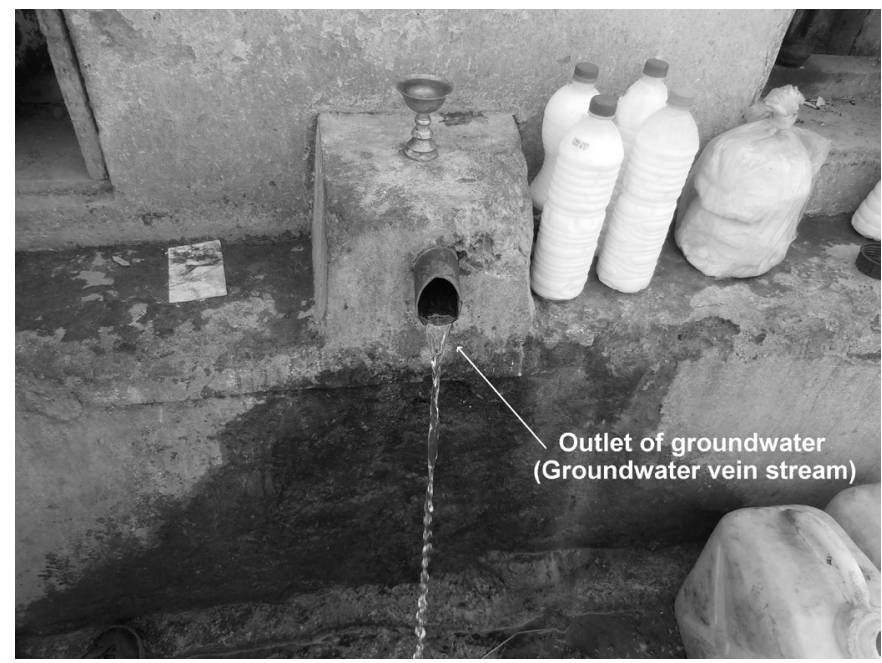

Fig. 18: The fountain of groundwater vein stream served as drinking water in 'No. e'.

In the potential landslide" No. b" on Higher Himalayan gneiss, presence of groundwater and its planar shape are not clear (Fig. 19). The overlying soil is from hard rock and the discontinuities are dipping towards the slope, so it can move downward if the toe of the slope is cut or groundwater pressure increases along the discontinuity.

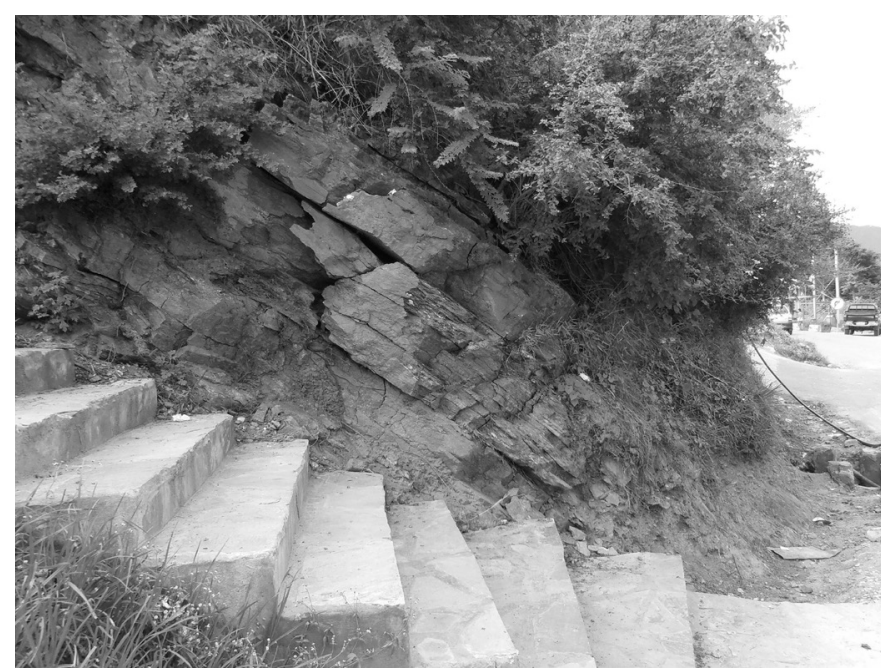

Fig. 19: The side view of 'No. b' which shows cuesta and has regular discontinuities.

The potential landslide "No. d" consists of soil deposited on slope and assumed to be thick. There is slope failure at the face of road cut as shown in Fig. 20. Groundwater is not documented in the area but the slope is cultivated field, so groundwater is assumed to exist. The main cause of the slope failure could be mainly cutting work. Groundwater is also assumed to be one of the causes of failure.

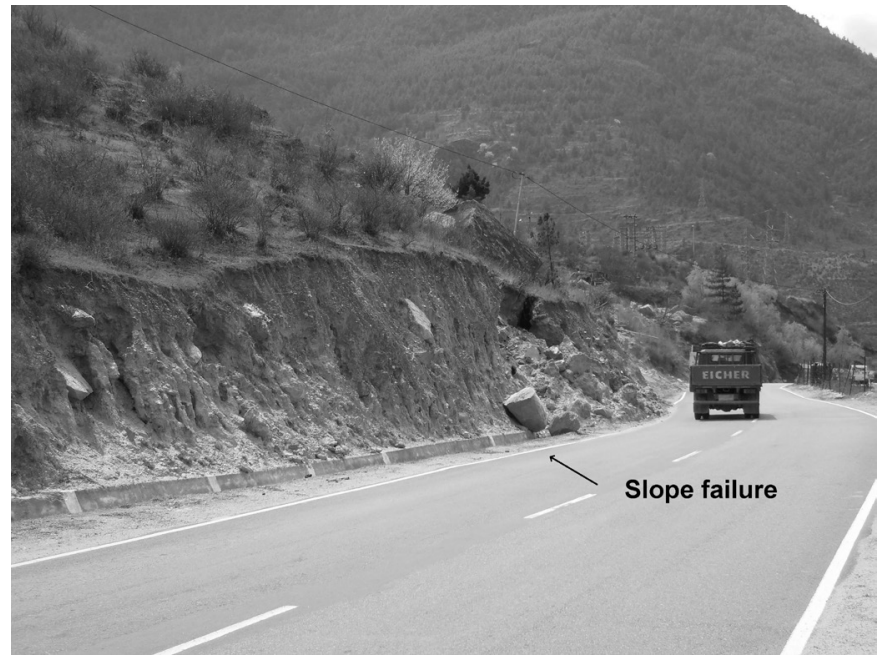

Fig. 20: The slope failure of the road cutting in 'No. d'.

The groundwater temperature measurement is effective for the potential landslides 'No. a', 'No. c' and 'No. e', and may be effective for 'No. b' and 'No. d'. Here, the habitants seldom meet the urgent needs to perform geological survey or mitigation work for landslide now. If the global climates change realises and gives influence such as increasing precipitation in this region, the potential landslides will be unstable to move and consequently will cause serious disaster. This is the reason why the ground temperature measurement is important in the contest of global climate change.

\section{DISCUSSION}

A case in Japan, groundwater vein stream was able to be found and mitigation work such as borings and wells were set at the location exactly by the results of the $1 \mathrm{~m}$ depth ground temperature measurement. As a result, the landslide that had moved with the speed of $20 \mathrm{~cm}$ per month was stopped. It is concluded that the ground temperature measurement and mitigation work like removing groundwater are effective method for landslide stabilisation.

In Thimphu, Bhutan, there are some potential landslides, but they seldom move now, because the average precipitation is only about $600 \mathrm{~mm}$ that is less than half of the introduced site in Japan, and consequently groundwater level may not be so high to lift the bottom of soil masses of landslide.

If the global climate change happens and precipitation increases much more than now, groundwater level will rise and make the potential landslides unstable to move. So, it is important to perform the groundwater temperature measurement in order to know where groundwater vein stream exists in the landslide area to design the mitigation work for it. This leads to address the negathine impact of the future climate change. 
The ground temperature measurement represented by the $1 \mathrm{~m}$ depth temperature measurement requires simple tools and instrument, and also can be done by a few persons. It is affordable and reliable because simple tools are inexpensive and durable. It is also sustainable because the process of measurement is easily understood and done with less cost. It cannot be a burden against environment either. The mitigation work such as drilling wells for withdrawing groundwater designed on the basis of the ground temperature measurement are much economical in comparison to prevention work such as pile hammering and ground anchor with concrete frame Sometimes, the prevention work mentioned above is necessary, but in many cases, it is enough to do the mitigation work of withdrawing groundwater as countermeasure.

The groundwater temperature measurement is effective for the potential landslides where groundwater exists and is presumed to be the cause of landslide movement. We assume that this is also effective in Bhutan.

\section{CONCLUSIONS}

The ground temperature measurement is effective for the potential landslides and is affordable and reliable because simple tools are inexpensive and durable. It is also sustainable because the process of measurement is easily understood and done with less cost. It can not be a burden against environment either. We recommend this method in order to confront the expecting landslide that may be assumed to be caused by global climate change in Bhutan.

\section{ACKNOWLEDGEMENT}

The authors would like to express heartfelt thanks to Hiromitsu Prof. Dr. Yamagishi who gave us valuable advice and to Prof. Dr. Vishnu Dangol who kindly provided us a chance to present our outcomes. They would also like to express their appreciation to the members of Thimphu City Corporation, who collaborated with our field investigation.

\section{REFERENCES}

Takeuchi A., 2013, The natural groundwater survey - $1 \mathrm{~m}$ depth ground temperature measurement. Kokonshoin, (in Japanese), $224 \mathrm{p}$.

RGB and JICA (Royal Government of Bhutan and Japan International Cooperation Agency), 2012, Meteorology in Bhutan, Thimpu, $38 \mathrm{p}$.

Yasuda, T. and Takeuchi, A., 2009, Research for existing of groundwater vein stream. The abstracts of presentation at fall meeting of Japanese Association of Groundwater Hydrology in 2009, (In Japanese).

Yasuda, T. and Takeuchi, A., 2012, Consideration for groundwater survey of landslide area. The abstracts of research publication meeting in Hokkaido branch in 2012, (In Japanese).

Yasuda, T., Takeuchi, A., Nunokawa, S., and Tanaka, N., 2009, A case of landslide disaster survey, reconfirming effectiveness of geophysical prospecting. The abstracts of research publication meeting in Hokkaido branch in 2009.

Varnes, D. J., 1978, Slope movement types and processes. In: Special Report 176: Landslides: Analysis and Control (eds. Schuster, R. L. and Krizek, R. J.). Transportation and Road Research Board, National Academy of Science, Washington D. C., pp. 11-33.

Japan Meteorological Agency, 2015, Home page of Japan Meteorological Agency http://www.jma.go.jp/jma/ indexe.html. Home $>$ Weather, Climate and Earthquake Information. Accessed in April 20, 2015.

Yoshida M., 2012, The worthy points of the geological tour in Bhutan 1 (In Japanese)., http://www.geocities.jp/ gondwanainst/geoplanningtour/Bhutan2013/HimalayaBhutan_Panf-1.pdf. Accessed in April 20, 2015. 